\title{
Changes in Determinants and Equity of Family Planning Utilization after the Implementation of a National Health Insurance Policy in Indonesia: A Secondary Analysis of The 2012-2016 National Socio-Economic Survey of Indonesia
}

Siti Khadijah Nasution ( $\sim$ Siti_Kd_Jah@yahoo.co.id)

Universitas Sumatera Utara https://orcid.org/0000-0001-8775-3993

Yodi Mahendradhata

Universitas Gadjah Mada

Laksono Trisnantoro

Universitas Gadjah Mada

Research article

Keywords: Equity, National Health Insurance, Family Planning, Indonesia

Posted Date: July 16th, 2019

DOI: https://doi.org/10.21203/rs.2.11463/v1

License: (c) (1) This work is licensed under a Creative Commons Attribution 4.0 International License.

Read Full License 


\section{Abstract}

Background The Indonesian government has been implementing the National Health Insurance Policy (Jaminan Kesehatan Nasional-JKN) since 2014. The utilization of family planning service is one of the programs to increase maternal and child health status that is included in the benefit package in JKN. This study aimed to describe determinants and to evaluate JKN based on equity indicators, especially in family planning services. Methods Data were obtained from the 2012-2016 National Socio-Economic Survey (SUSENAS) of Indonesia. Contraceptive Prevalence Rate (CPR) and Long-acting contraceptives (LACs) use were used as indicators to evaluate family planning utilization. Chi-square and logistic regression tests were used to analyze the data. Respondents were married women between 15 and 49 years of age. Results There was no progress in CPR after the implementation of JKN. At the national level, CPR decreased within five years (2012-2016). Decreasing in urban areas and in the group that does not have health insurance were more than in rural areas and in the group that has health insurance. Utilization of non-LACs, especially injection (56\%-57\%) and pill (21\%-24\%), were still high within 20122016. At the national level, LACs use increased 3.18\% between 2012-2016 (15.54\%-18.72\%). Increasing in urban areas and in the group that has subsidized health insurance were more than in rural areas and in the group that does not have subsidized. Health insurance ownership, the geography factor, education, household economic correlated with contraceptive use $(p<0.05)$ in 2015 and 2016 , but this correlation was inversely proportional. Conversely, all of the determinants were positively associated with LACs use $(p<0.05)$. Conclusions Up to 2016, the JKN program did not increase CPR. Conversely, the JKN program obtained only small increases in LACs use. LACs use in rural areas is less than in urban areas. JKN program can increase LACs use in the group that has subsidized health insurance. CPR and LACs coverage could be increased by health system improvement and the social approaches, specifically through improving supply-side and regulations, increasing coordination among multiple agencies in the family planning program, and promoting family planning based on values and norms in the society.

\section{Background}

In 2015, the Maternal Mortality Ratio (MMR) in Indonesia was reported 305 per 100,000 live births, while Infant Mortality Rate (IMR) was reported 22.23 per 1000 live births [1]. This achievement is not yet in line with the target of Millennium Development Goals (MDGs). The target of MMR in Indonesia is 110 per 100,000 live births in 2015, while IMR is 19 per 1000 live births [2]. After MDGs finished in 2015, all United Nations Member States adopted the 2030 agendas for sustainable development. To achieve the third goal in Sustainable Development Goals (SDGs) viz. every country reaches MMR less than 70 per 100,000 live births and IMR less than 12 per 1000 live births in 2030 [3], Indonesia has been implementing many programs that are related with maternal and child health.

The family planning program is one of the ways to increase maternal and child health. Ensuring access to contraceptive use contributes to the success of the family planning program. Contraceptive use through reduction of fertility reduces maternal and neonatal mortality $[4,5]$. Contraceptive use, especially 
Long-acting contraceptives (LACs) methods, prevents unintended pregnancy while reducing abortions, as shown by prior research [6].

The success of the family planning programs could be evaluated based on the Contraceptive Prevalence Rate (CPR) and LACs use. Beginning in 1976, when the role of the national population and family planning board (Badan Koordinasi Keluarga Berencana Nasional, or BKKBN) was powerful, the family planning program in Indonesia showed significant success. During 1976-2002, CPR increased from $26 \%$ to $60 \%$. After 2002 , in the decentralization era, CPR increased very slowly and tended to stagnant between 2002-2012. Moreover, CPR tended to decrease after 2012 [1,7-10]. The target of CPR in the 2015-2019 Indonesian national development is $66 \%$, while the target of LACs use is $23.5 \%$ [11]. One of the obstacles to accessing family planning programs is finances, especially for the poor. To reduce the financial barrier, the Indonesian government has been implementing a National Health Insurance Policy (Jaminan Kesehatan Nasional-JKN) since 2014 [12]. The family planning program is included in the benefit package in JKN [13]. JKN is a social health insurance and compulsory insurance that was implemented gradually to achieve universal coverage in 2019 . In early $2014,49 \%$ of the population had insurance coverage. In $2016,66.46 \%$ of the population had insurance coverage. At the end of 2019 , all Indonesian people are expected to be protected by health insurance [12-15]

One of the indicators used to assess the success of social health insurance is equity. It is consistent with one of the goals in SDGs, specifically to reduce the health gaps inside a country and between countries. Equity is defined as no number and/or difference of frequency of using health services based on socioeconomic status [16]. In meeting this challenge, Indonesia with 34 provinces confronts a wide diversity and divergence in maternal health status and maternal health service utilization.

Evaluation is needed to measure the influence of the JKN policy on utilization and equity progress of the family planning program. Data within five periods (2012-2016) enable us to analyze the progress of equity. Based on the National Socio-Economic Survey (Survei Sosial Ekonomi Nasional-SUSENAS) data, we aimed to investigate and describe the progress of utilization and equity in the family planning program and its connections with health insurance ownership, education, household economic status, and geography factor. Findings from this study are expected to provide baseline information for Indonesia policy-makers to improve JKN policy related to the family planning program.

\section{Methods}

\section{Study design}

In this research, a cross-sectional study was performed based on the national secondary database provided by SUSENAS. SUSENAS is one of the regular surveys conducted by the government of Indonesia through the Central Bureau of Statistics (Badan Pusat Statistik-BPS) every year. Data were collected with a questionnaire. The data contain information on the socio-economic conditions of society, including 
health conditions, education, fertility, family planning, and housing. SUSENAS surveys include, on average, 300,000 households every year that are spread over 34 provinces and 511 districts/cities in Indonesia. SUSENAS has been conducted since 1979. The sample design of the SUSENAS, which uses probability sampling, allows for the estimation of district-level coverage. Detailed information about the survey and the sampling design with census block allocation are available at http:// microdata.bps.go.id/mikrodata/index.php (in Bahasa) [17].

\section{Study site}

Indonesia, the largest archipelago in the world, consists of five main islands and 13,677 small islands. Until 2014, the number of provinces in Indonesia was 33 provinces. In 2015, Indonesia was divided into 34 provinces and 511 districts/cities. The five main islands in Indonesia are Sumatera, Jawa, Kalimantan, Sulawesi, and Papua. Sumatera, Jawa, Kalimantan are islands in the western areas of Indonesia. Sulawesi, Papua, and some small islands (Nusa Tenggara Timur, Nusa Tenggara Barat, Maluku) are islands in the eastern areas of Indonesia .

\section{Population}

\section{Source population}

The source population for this study was households that were included in the Indonesian National Socio-Economic Survey Data (SUSENAS) 2012-2016.

\section{Database population}

Database population that was taken from SUSENAS 2012-2016 included households that had married woman (15-49).

\section{Study population}

The study population included the married woman (15-49).

\section{Sample size}

A national representative sample of 200,367 (2012), 195,040 (2013), 195,607 (2014), 193,245 (2015), 191,490 (2016) married woman (15-49) were selected for this study. 


\section{Variables and definitions}

Independent variables were health insurance ownership, education, household economic status, and geography factor. Dependent variables were contraceptive use and LACs use by participants.

Contraceptive use accumulation obtained CPR and LACs use. Definition of CPR is the percentage of women aged 15-49 years, married, who are currently using, or whose sexual partner is using, at least one method of contraception, regardless of the method used. While, the definition of LACs use is the percentage of women aged 15-49 years, married, who are currently using, or whose sexual partner is using, at least one method of LACs methods, i.e. implant, intrauterine device (IUD), vasectomy, and tubal ligation. We created dichotomous variables for all categories using binary numbers. In the contraceptive use variable, we used 1 for not a contraceptive user and 0 for a contraceptive user. In LACs use, we used 1 for not a LACs user and 0 for LACs user. Health insurance ownership was scored as 1 for not having health insurance and 0 for having health insurance. The geography factor was scored as 1 for household location in a rural area and 0 for household location in an urban area. Education was scored as 1 for illiterate-middle and 0 for high secondary or above. Household socio-economic status was measured using household expenditures, with 1 representing $50 \%$ of the lowest and 0 representing $>50 \%$ of the highest.

\section{Statistical analysis}

The analysis was done using Stata version 13.1. The analysis was performed with chi-square $\left(\mathrm{X}^{2}\right)$ test for categorical variables. The association between dependent and independent variables was measured using the odds ratio (OR), for which the $95 \%$ confidence interval $(\mathrm{Cl})$ was calculated. Variables were determined to be statistically significant if the result indicated $p<0.05$. Variables that showed a statistically significant association $(p<0.25)$ at the bivariable level were further analyzed at the multivariable level by logistic regression.

\section{Ethics}

The raw data of SUSENAS 2012-2016 were used for this study with permission from the Central Bureau of Statistics (BPS). Informed consent was obtained from all study participants by the BPS.

\section{Results}

\section{Descriptive statistics}

The achievement in CPR during 2012-2016 has shown variation in every province. CPR in the eastern areas of Indonesia, especially Nusa Tenggara Timur, Papua Barat, Maluku, and Papua was less than in the western areas. After the implementation of JKN in 2014, this situation did not change. In general, 
almost all of the provinces decreased in CPR. At the national level, CPR decreased as much as $2.41 \%$. (See Table 1).

The data showed that CPR declined every year (2012-2016) in all of the regions. The decline in urban areas was more than in rural areas between 2012-2016. The decline in the group that did not have health insurance was more than in the group that did. The decline in the non-subsidized health insurance group or the rich group was more than in the subsidized health insurance group or the poor group. In 2013, there was an increase in contraceptive use in the subsidized health insurance group. Preference of non-LACs methods was more common than LACs methods. While there was only a small increase in LACs use during 2012-2016, preference of contraceptive methods was still dominated by the pill and injection. (See Table 2)

On the contrary, the achievement in LACs use during 2012-2016 has shown an increase in every province except Sulawesi Tenggara. Bali had the highest LACs use within the five years. The highest growth was in Papua. At the national level, LACs use increased as much as 3.18\% during 2012-2016. There was a rising trend after the implementation of JKN in 2014. (See Table 4)

LACs use in the eastern areas of Indonesia, and especially the Nusa-Maluku-Papua region indicated a rising trend during 2012-2016. LACs use in urban areas increased more than in rural areas during 20122016. LACs use in the group that has health insurance was more than in the group that did not. LACs use in the subsidized health insurance group showed a rising trend after the implementation of JKN in 2014. (See Table 5)

\section{Bivariable Analysis}

At the national level, in 2012, a significant correlation between health insurance ownership and contraceptive use was found, but this correlation was inversely proportional. On the contrary, in 2013, its correlation was directly proportional. In 2014, the first year of JKN, the result showed no correlation. Moreover, in 2015 and 2016, the result showed some correlation, but it was inversely proportional. At the provincial level, not all of the provinces indicated a positive significant result. In 2016, positive significant result was found in only nine of the 34 provinces. On the contrary, at the national level, a positive significant correlation was found between health insurance ownership and LACs use in every year (20122016). At the provincial level, the result showed a rising trend in the number of provinces that indicated the positive significant result after the implementation of JKN. (See Table 3\&6)

Chi-square analysis indicated some factors that significantly correlated with contraceptive use. Only in 2013 , health insurance ownership exhibited a positive influence on contraceptive use. In 2014, the first year of the JKN policy, there was no influence between health insurance ownership and contraceptive use. Furthermore, there was an inversely proportional correlation in 2015 and 2016. Participants who did not have health insurance were more likely to use contraceptive than those who did have health insurance. The education factor and household economic status exhibited influence on contraceptive use 
within 2012-2016, but it was inversely proportional. Participants with illiterate or middle education had a greater probability of using contraceptives than those with high secondary education levels or higher . More than half of the households that had the lowest expenses had a higher likelihood of using contraceptives than $50 \%$ of households that had the highest expenses. The geography factor influenced contraceptive use after the implementation of JKN, but it was inversely proportional. Households located in rural areas had an even higher probability of using contraceptives than did households located in urban areas. (See Table 7)

Chi-square analysis indicated some factors that were significantly correlated to LACs use. Health insurance ownership, education, household economy, and geography factor exhibited a positive influence on LACs use within 2012-2016. This influence was stable during 2012-2016. Participants who have health insurance were more likely to use LACs methods than the group that did not have health insurance. Participants with high secondary or above education were more likely to use LACs methods than those in the illiterate or middle education level. More than half of participants who had the highest expense were more likely to use LACs methods than $50 \%$ of households that had the lowest expenses. Households located in urban areas were more likely to use LACs methods than households located in rural areas. (See Table 8)

Multivariable Analysis

The influence of health insurance ownership on contraceptive use decreased after the implementation of JKN. The influence of education and household economic status as the dominant factors on contraceptive use were inversely proportional and their influence tended to be stable during 2012-2016. The influence of the geography factor on contraceptive use exhibited a trend to decrease between 20122016. (See Table 9)

The influence of health insurance ownership, education, household economic status, and geography factor on LACs increased after the implementation of JKN. Compared to the other factors, household economic status had the lowest contribution between 2012-2016. The education factor as the highest contribution became the dominant factor to influence LACs use between 2012-2016. (See Table 10)

\section{Discussion}

The influence of health insurance ownership, socio-economic status, and geography factor, on contraceptive use and LACs use, indicated some contrary results. JKN policy did not increase contraceptive use in married women between 15 and 49 years of age, but JKN policy could increase LACs use. An inversely proportional correlation between socio-economic status and contraceptive use was found, while in LACs use was directly proportional. There was a tendency to increase contraceptive use by married women between 15 and 49 years of age in rural areas after the implementation of JKN. On the contrary, LACs use increased more in urban areas than in rural areas after the implementation of JKN. 
The results of this research showed that JKN did not increase CPR at the national level, and it also did not increase equity in family planning use among regions, especially the eastern areas of Indonesia.

This research had some limitations, which need to be considered when interpreting the results. First, not all of the variables that should be considered exist in the secondary data. Some variables that could have influenced CPR and LACs use are not available in SUSENAS data, such as availability of health facilities and contraceptives, and the distance of health facilities from the locality of residence. We only identified four determinants that contribute to contraceptive use or CPR and LACs use. Second, we only used a before-after approach with a cross-sectional design to measure equity of family planning utilization. This is one of the standard methods used in health impact assessment. Third, this study only measured equity in utilization of contraceptive use and LACs use. Equity in health financing could not be measured because of data limitations.

Even though our study has some limitations, quantitative analysis was able to be conducted in every province by using large samples. Thus, the result for every province may be generalized. Data with large samples in 2012-2016 were able to measure the change of equity every year and the change of socioeconomic determinants and the geography factor that influence contraceptive use or CPR and LACs use.

One of the objectives of the national health insurance implementation is to ensure all people get access to health services. Reducing the financial barriers to access health services will increase health services utilization. In fact, JKN has not increased contraceptive use that is included in the benefit package in JKN. Moreover, there was a decreasing trend of contraceptive use in married women between 15 and 49 years of age who have health insurance after the implementation of JKN. Research by Teplitskaya et al. supports this finding [7]. After 2002, CPR tended to decrease in the decentralization era because of the reduction in funding of family planning and the diminishing role of BKKBN as the leading service provider [10]. This problem continues to occur after the implementation of JKN since there are now multiple agencies that have a role in the family planning program, i.e. BKKBN, the Ministry of Health $(\mathrm{MOH})$, the National Health Insurance Agency (Badan Pelaksanan Jaminan Sosial-Kesehatan or BPJS-K), while the local governments have a lack of coordination. In other words, there is fragmentation among multiple agencies [18].

The central and local governments provide drugs and contraception, while BKKBN has the role in fulfilling and distributing it in health service centers. BPJS finances the tariff of family planning services in health service centers based on the laws of the Indonesian Health Ministry [12,13,19-21]. Besides the lack of coordination among multiple agencies, the reducing trend of CPR after the implementation of JKN can occur because of the weak regulations. Some regulations related to family planning programs in JKN must be evaluated, viz. non-capitation tariff for IUD and sterilization is assumed too low, no limitation to births, no claim for IUD in hospital, and no guarantee for sterilization after delivery [22]. When the government implemented childbirth insurance, called Jaminan Persalinan-Jampersal, in 2011, there were some provisions to encourage the participants enrolled in Jampersa/to join in post-partum family planning. This law did not continue in the JKN era [23]. 
JKN policy did not increase equity in contraceptive use among regions. The achievement of CPR in the eastern areas of Indonesia was still lower than in the western areas of Indonesia, but LACs coverage in the eastern areas of Indonesia increased more than in the western areas of Indonesia. The new policy that encourages LACs use coverage in the eastern of Indonesia can be a solution to increase CPR in the eastern areas of Indonesia. To achieve it, the government must strengthen the quality and equitable distribution of the supply side. Gaps in infrastructure, health facilities, and health workers between the western and eastern areas of Indonesia have already been observed in the first year of the implementation of JKN [18]. This problem continued to occur after the implementation of JKN.

Some countries that had implemented maternal health insurance for deliveries and mothers' postpartum care through universal health coverage agenda showed different results. Mauritania had implemented the obstetrical risk insurance scheme (ORI) in 2002, but the effects of the ORI exhibited decreasing use of family planning [24]. The implementation of universal health coverage (UHC) in Latin America showed mCPR has continued to increase in the majority of Latin America Countries, but disparities remain, especially for marginalized groups [25]. The implementation of Affordable Care Act (ACA) mandate in United States (US) that also required contraceptives package in private health insurance indicated significant results to increase contraceptive and Long Acting Reversible Contraceptives (LARCs) use, to decrease the births, to reduce the proportion of births from unwanted pregnancies, and to reduce an inequality among insured women [6,26-35].

Not only health insurance ownership but also socio-economic status and the geography factor contributed to contraceptive use. Education and household economic status showed a significant result, but the association was inversely proportional. It means the higher education and household economic status the less contraceptive use. These results contrast with the prior research that used the 2002-2003 and 2007 of Indonesia Demographic and Health Survey (IDHS) Indonesia and some other studies. The 2002-2003 and 2007 of IDHS indicated that better off and educated women were more likely to use family planning than were the poor and uneducated women $[9,10]$. The conflicting results in two periods, between 2002-2007 and 2012-2016, indicated that there is a significant transformation in the society. We assumed that there is a shift of values in the society in Indonesia, but this assumption must be proved through further qualitative research. The same results were shown by studies in Bangladesh and Cameroon [36-38], but the studies in North Ethiopia and Malawi showed that education contributes significantly to contraceptive use $[39,40]$. Although the association between the geography factor and contraceptive use showed a significant result, the gap in contraceptive use between urban and rural areas decreased after the implementation of JKN. Moreover, in 2016, the result showed that married women in rural areas were more likely to contraceptive use than were married women in urban areas. In other words, JKN contributed to decreasing inequity in contraceptive use between urban and rural areas, but an inequity gap between provinces in the western areas and in the eastern areas of Indonesia has remained.

On the contrary with determinants of contraceptive use, the influence of health insurance ownership, socio-economic status, and geography factor, on LACs use indicated significant results, which were directly proportional. JKN policy could increase LACs use in married women between 15 and 49 years of 
age, especially in the group who has subsidized health insurance and in the Nusa-Maluku-Papua region, but an inequity has remained between urban and rural areas. Most studies indicated that health insurance has made a significant contribution to increase LACs use $[6,26-30,32-35,41-46]$. The contribution of LACs use in the success of the family planning program is very crucial, but until 2016, LACs use coverage in Indonesia was only $18.72 \%$. To increase contraceptive use, especially LACs use, the Indonesian government must evaluate the prior policies related to family planning policies.

Health system improvement related to family planning programs must be prioritized. Some specific actions must be done. First, the government must strengthen the quality and equitable distribution of the supply side for the family planning program, especially in the rural and the eastern areas of Indonesia. Second, strengthening of the role and coordination among multiple agencies in the family planning program must be implemented. Third, improving regulations is needed related to family planning programs in JKN, for example, increasing of non-capitation tariff for IUD and sterilization; providing of IUD service in hospital; and encouraging of family planning after post-partum. Some studies had also suggested increasing family planning among post-partum women $[47,48]$. Besides improving the health system, the shift of values in the Indonesian society that encourages acceptance of family planning must be evaluated. The social approaches based on values and norms in the society are needed to increase contraceptive use, especially LACs use.

To ensure that the married women between 15 and 49 years of age who are covered by National Health Insurance (NHI) get the optimal services of family planning, the supply-side of family planning programs, ability to manage by multiple agencies in family planning programs, and the regulations related to family planning in $\mathrm{NHI}$ must be properly prepared before and during the implementation of $\mathrm{NHI}$. Every kind of health service that is included in the $\mathrm{NHI}$ package has a unique problem in its implementation, and as a result, every health service must have appropriate regulations that are suitable to overcome the problem.

\section{Conclusions}

$\mathrm{NHI}$, called JKN, that has been implemented in Indonesia since 2014 did not increase contraceptive use or CPR. Instead, contraceptive use had a decreasing trend after the implementation of JKN. There were significant correlations of health insurance ownership, socio-economic status, and the geography factor with contraceptive use, but the association was inversely proportional. On the contrary, JKN could increase LACs use, although only slightly, while there was significant association of all determinants with LACs use which was directly proportional.

Health system improvements and implementation of innovative social approaches provide some solutions to increase both contraceptive use and LACs use. Integrating health system improvements through the strengthening of supply-side, coordinating multiple agencies in family planning program, and enacting effective regulations and policies are needed. The success of the family planning 
implementation in Indonesian society cannot be separated with values and norms in society, so the social approaches must become one of the policies for the success of family planning programs.

\section{Abbreviations}

NHI: National health insurance; MMR: Maternal mortality ratio; IDHS: Indonesia Demographic health survey; SUSENAS: Survei sosial ekonomi nasional; JKN:Jaminan Kesehatan Nasional; BPS: Badan Pusat Statistik; LACs: Long-Acting Contraceptives; CPR: Contraceptive Prevalence Rate; IUD: Intra-Uterine Device.

\section{Declarations}

\section{Ethics approval and consent to participate}

We used the secondary data. The raw data of SUSENAS 2012-2016 were used for this study with permission from the Indonesian Central Bureau of Statistics (Biro Pusat Statistik-BPS). Informed consent was obtained from all study participants by BPS. Participants were married women between 15 and 49 years of age. The Medical and Health Research Ethics Committee (MHREC) Faculty of Medicine Gadjah Mada University, Indonesia states that documents (the research protocol) do not need approval letter of The Medical and Health Research Ethics Committee (MHREC) (Ref : KE/FK/1151/EC/2017).

\section{Consent for publication}

Not applicable

\section{Availability of data and material}

The data that support the findings of this study are available from the Indonesian Central Bureau of Statistics (BPS) but restrictions apply to the availability of these data, which were used under license for the current study, and so are not publicly available. Data are however available from the authors upon reasonable request and with permission of the Central Bureau of Statistics (BPS).

\section{Competing interests}

The authors declare that they have no competing interests. 


\section{Funding}

The source of funding for this research is from authors.

\section{Authors' contributions}

SKN and LT conceptualized the study. SKN prepared the first draft of the manuscript. SKN acquired the raw data for analysis. YM played a major role in structuring arguments and smoothing out the text. LT contributed to conceptualizing and conceived the idea for the paper. All authors read and approved the final manuscript.

\section{Acknowledgements}

We are grateful to the Central Bureau of Statistics (Badan Pusat Statistik, or BPS) Indonesia for providing us with the raw data from SUSENAS or National Socio-Economic Survey.

\section{Author details}

${ }^{1}$ Department of Administration and Health Policy, Faculty of Public Health, Universitas Sumatera Utara, Indonesia

${ }^{2}$ Department of Health Policy and Management, Faculty of Medicine, Public Health and Nursing, Universitas Gadjah Mada, Indonesia

\section{References}

1. Kementerian Kesehatan Republik Indonesia. Laporan Tahunan Ditkesga Kemenkes RI 2016 [Annual Report: Directorate of Family Health, The Ministry of Health Indonesia 2016].

http://kesga.kemkes.go.id/images/pedoman/Laptah\%20TA\%202016\%20Dit\%20Kesga.pdf. Accessed 14 Nov 2018.

2. Stalker P. Millenium development goals: Kita suarakan MDGS demi pencapaiannya di Indonesia. 2008; A report by Bappenas and UNDP. https://www.undp.org/content/dam/indonesia/docs/MDG/Let\%20Speak\%200ut\%20for\%20MDGs\%20\%20ID.pdf 
3. The United Nations. Sustainable Development Knowledge Platform. https://sustainabledevelopment.un.org/sdgs. Accessed 14 Nov 2018.

4. Girum T, Wasie A. Correlates of maternal mortality in developing countries: an ecological study in 82 countries. Matern Heal Neonatol Perinatol. 2017;3(1):19. Available from:

http://mhnpjournal.biomedcentral.com/articles/10.1186/s40748-017-0059-8

5. Stover J, Ross J. How increased contraceptive use has reduced maternal mortality. Matern Child Health J. 2010;14(5):687-95.

6. Pickle S, Wu J, Burbank-Schmitt E. Prevention of unintended pregnancy: a focus on long-acting reversible contraception. Prim Care - Clin Off Pract. 2014;41(2):239-60. Available from: http://dx.doi.org/10.1016/j.pop.2014.02.004

7. Lyubov Teplitskaya RR and AD. Has the Indonesian National health insurance improved family planning. 2019;(May 2018). Available from: http://www.healthpolicyplus.com/ns/pubs/82268396_HPPlusIndonesiaJNKAccessFPservicesBrief.pdf

8. BKKBN. Strategi Pelaksanaan Program Keluarga Berencana Berbasis Hak untuk Percepatan Akses terhadap Pelayanan Keluarga Berencana dan Kesehatan Reproduksi yang Terintegrasi dalam Mencapai Tujuan Pembangunan Indonesia. 2015;100. A report by BKKBN.

9. Rahayu R, Utomo I, Mcdonald P. Contraceptive use pattern among married women in Indonesia. Int Conf Fam Plan Res Best Pract. 2009;36.

10. Juan B, Schoemaker J. 3110605-5. 2003;106-14.

11. Pemerintah RI. Rencana Pembangunan Jangka Menengah Nasional 2015-2019 [The 2015-2019 Plan of National Medium Term Development]. https://www.socialprotection.org/gimi/gess/RessourcePDF.action?ressource.ressourceld=50077. Accessed 14 Nov 2018.

12. Pemerintah RI. Undang-Undang RI No.40 Th.2004 tentang Sistem Jaminan Sosial Nasional[The Law of Indonesia Republic No.40/2004; National Social SecuritySystem].

https://www.hukumonline.com/pusatdata/detail/19788/node/186/uu-no-40-tahun-2004-sistem-jaminansosial-nasional. Accessed 14 Nov 2018.

13. Pemerintah RI. Undang-Undang No.24 Tahun 2011 tentang Badan Penyelenggaran Jaminan Sosial [The Law of Indonesia Republic No.24/2011; Social Security Agency in Indonesia].

https://search.hukumonline.com/id/search/browse?q=UndangUndang+Nomor+24+Tahun+2011+bpjs\&category=all. Accessed 14 Nov 2018.

14. Rusady MA. Peranan BPJS Kesehatan Dalam Peningkatan Pelayanan Kesehatan [The role of BPJS to increase health services]. Report by BPJS.2017. 
15. Indonesian Ministry of Health. Profil Kesehatan Indonesia 2016 [The 2016 Indonesia Health Profile, Kementerian Kesehatan Republik Indonesia. 2017. Available from:

http://www.depkes.go.id/resources/download/pusdatin/profil-kesehatan-indonesia/Profil-KesehatanIndonesia-2016.pdf

16. Braveman P, Gruskin S. Defining equity in health 10.1136/jech.57.4.254. J Epidemiol Community Health. 2003;57(4):254-8. Available from: http://jech.bmj.com/content/57/4/254.abstract

17. BPS RI. Survei Sosial Ekonomi Nasional-SUSENAS 2012-2016 [The 2012-2016 Indonesia National Socio-Economic Survey]. http:// microdata.bps.go.id/mikrodata/index.php (in Bahasa).

18. Trisnantoro L. Kebijakan Pembiayaan dan Fragmentasi Sistem Kesehatan [Financing Policy and Health System Fragmentation]. Gadjah Mada University Press; 2019.

19. Pemerintah RI. Undang-Undang No.23 Tahun 2014 tentang Pemerintah Daerah [The Law of Indonesia Republic No.23/2014; Local Government].

20. Pemerintah RI. Peraturan Presiden Republik Indonesia No. 19 Tahun 2016 tentang Perubahan Kedua atas Peraturan Presiden No. 12 tahun 2013 tentang Jaminan Kesehatan. Pemerintah Rl. [The Law of Indonesia Republic No.19/2016]

21. Pemerintah RI. Undang-Undang No.36 Tahun 2009 tentang Kesehatan [The Law of Indonesia Republic No.36/2009; Health].

22. Siswosudarmo R. The Utilisation of Post-partum Family Planning. Presented in National Forum of Maternal and Child Health, Universitas Gadjah Mada, Indonesia, 2018.

23. Pemerintah RI. Permenkes 2562/Menkes/PER/XII/2011 [The Law of Health Ministry No.2562/2011].

24. Philibert A, Ravit M, Ridde V, Dossa I, Bonnet E, Bedecarrats F, et al. Maternal and neonatal health impact of obstetrical risk insurance scheme in Mauritania: A quasi experimental before-and-after study. Health Policy Plan. 2017;32(3):405-17.

25. Fagan T, Dutta A, Rosen J, Olivetti A, Klein K. Family planning in the context of Latin America's Universal Health Coverage agenda. Glob Heal Sci Pract. 2017;5(3):382-98. Available from: http://www.ghspjournal.org/lookup/doi/10.9745/GHSP-D-17-00057

26. Dills AK, Grecu AM. Effects of state contraceptive insurance mandates. Econ Hum Biol. 2017;24:3042. Available from: http://dx.doi.org/10.1016/j.ehb.2016.11.004

27. Thompson KMJ, Rocca CH, Kohn JE, Goodman S, Stern L, Blum M, et al. Public funding for contraception, provider training, and use of highly effective contraceptives: A cluster randomized trial. Am J Public Health. 2016;106(3):541-6. 
28. Durante JC, Woodhams EJ. Patient education about the Affordable Care Act contraceptive coverage requirement increases interest in using long-acting reversible contraception. Women's Health Issues [Internet]. 2017;27(2):152-7. Available from: http://dx.doi.org/10.1016/j.whi.2016.11.006

29. Jones RK, Sonfield A. Health insurance coverage among women of reproductive age before and after implementation of the affordable care act. Contraception. 2016;93(5):386-91. Available from: http://dx.doi.org/10.1016/j.contraception.2016.01.003

30. Bornstein M, Carter M, Zapata L, Gavin L, Moskosky S. Access to long-acting reversible contraception among US publicly funded health centers. Contraception. 2018;97(5):405-10. Available from: https://doi.org/10.1016/j.contraception.2017.12.010

31. Sonfield A, Tapales A, Jones RK, Finer LB. Impact of the federal contraceptive coverage guarantee on out-of-pocket payments for contraceptives: 2014 Update. Contraception. 2015;91(1):44-8. Available from: http://dx.doi.org/10.1016/j.contraception.2014.09.006

32. Dunlop AL, Adams EK, Hawley J, Blake SC, Joski P. Georgia's Medicaid family planning waiver: working together with Title $X$ to enhance access to and use of contraceptive and preventive health services. Women's Health Issues. 2016;26(6):602-11. Available from:

http://dx.doi.org/10.1016/j.whi.2016.07.006

33. Adams EK, Galactionova K, Kenney GM. Medicaid family planning waivers in 3 states: did they reduce unwanted births? Inq (United States). 2015;52.

34. Bearak JM, Finer LB, Jerman J, Kavanaugh ML. Changes in out-of-pocket costs for hormonal IUDs after implementation of the Affordable Care Act: An analysis of insurance benefit inquiries.

Contraception. 2016;93(2):139-44. Available from:

http://dx.doi.org/10.1016/j.contraception.2015.08.018

35. Parks C, Peipert JF. Eliminating health disparities in unintended pregnancy with long-acting reversible contraception (LARC) Presented in part at the 2013 annual meeting of the American Gynecological and Obstetrical Society. Am J Obstet Gynecol. 2016;214(6):681-8. Available from: http://dx.doi.org/10.1016/j.ajog.2016.02.017

36. Hossain M, Khan M, Ababneh F, Shaw J. Identifying factors influencing contraceptive use in Bangladesh: evidence from BDHS 2014 data. BMC Public Health. 2018;18(1):1-14.

37. Kibria GM Al, Burrowes V, Majumder S, Sharmeen A, Barsha RAA, Hossen S. Scaling up contraceptives use in the division with lowest contraceptives use in Bangladesh: sources, methods, and determinants. Matern Heal Neonatol Perinatol. 2017;3(1):10. Available from: http://mhnpjournal.biomedcentral.com/articles/10.1186/s40748-017-0049-x 
38. Njotang PN, Yakum MN, Ajong AB, Essi MJ, Akoh EW, Mesumbe NE, et al. Determinants of modern contraceptive practice in Yaoundé-Cameroon: A community based cross sectional study. BMC Res Notes. 2017;10(1):4-9.

39. Medhanyie AA, Desta A, Alemayehu M, Gebrehiwot T, Abraha TA, Abrha A, et al. Factors associated with contraceptive use in Tigray, North Ethiopia. Reprod Health. 2017;14(1):1-11.

40. Mandiwa C, Namondwe B, Makwinja A, Zamawe C. Factors associated with contraceptive use among young women in Malawi: analysis of the 2015-16 Malawi demographic and health survey data.

Contracept Reprod Med. 2018;3(1):12. Available from:

https://contraceptionmedicine.biomedcentral.com/articles/10.1186/s40834-018-0065-x

41. Holton S, Rowe H, Kirkman M, Jordan L, McNamee K, Bayly C, et al. Long-acting reversible contraception: findings from the Understanding Fertility Management in Contemporary Australia Survey. Eur J Contracept Reprod Heal Care. 2016;21(2):116-31. Available from:

http://dx.doi.org/10.3109/13625187.2015.1052394

42. Riddell L, Taylor R, Alford O. Impact of the Affordable Care Act on Use of Covered Contraceptives in Women Ages 20-25. Popul Health Manag. 2017;00(00):pop.2017.0050. Available from: http://online.liebertpub.com/doi/10.1089/pop.2017.0050

43. Kim NH, Look KA. Effects of the Affordable Care Act's contraceptive coverage requirement on the utilization and out-of-pocket costs of prescribed oral contraceptives. Res Soc Adm Pharm. 2018;14(5):479-87. Available from: https://doi.org/10.1016/j.sapharm.2017.06.005

44. Broecker J, Jurich J, Fuchs R. The relationship between long-acting reversible contraception and insurance coverage: a retrospective analysis. Contraception. 2016;93(3):266-72. Available from: http://dx.doi.org/10.1016/j.contraception.2015.11.006

45. Law A, Pilon D, Lynen R, Laliberté F, Gozalo L, Lefebvre P, et al. Retrospective analysis of the impact of increasing access to long acting reversible contraceptives in a commercially insured population. Reprod Health. 2016;13(1). Available from: http://dx.doi.org/10.1186/s12978-016-0211-3

46. Kumar N, Brown JD. Access barriers to long-acting reversible contraceptives for Adolescents. J Adolesc Heal. 2016;59(3):248-53. Available from: http://dx.doi.org/10.1016/j.jadohealth.2016.03.039

47. Potter JE, Coleman-minahan K, White K, Powers DA, Dillaway C, Stevenson AJ. Texas: use compared with preference. Obstet Gynecol. 2018;130(2):393-402.

48. Wilopo SA, Setyawan A, Pinandari AW, Prihyugiarto T, Juliaan F, Magnani RJ. Levels, trends and correlates of unmet need for family planning among postpartum women in Indonesia: 2007-2015. BMC Womens Health. 2017;17(1):1-14. 


\section{Tables}

Table 1. Percentage of contraceptive use in married woman between 15 and 49 years of age

\begin{tabular}{|c|c|}
\hline Province & $201220132014201520162012-2016$ \\
\hline Bangka Belitung & $\begin{array}{ll}67.5 & 69.6966 .9867 .0369 .532 .03\end{array}$ \\
\hline Kalimantan Selatan & $69.9269 .3670 .1270 .5569 .38-0.54$ \\
\hline Lampung & $67.8669 .2268 .3867 .8 \quad 69.291 .43$ \\
\hline Sumatera Selatan & 68.8968 .6968 .0669 .3568 .950 .06 \\
\hline Bengkulu & $70.3471 .3970 .3869 .2 \quad 68.71-1.63$ \\
\hline Kalimantan Tengah & $70.9 \quad 72.6171 .8169 .1966 .3 \quad-4.6$ \\
\hline Kalimantan Barat & $69.1167 .4568 .7465 .9166 .04-3.07$ \\
\hline Sulawesi Utara & $69.5966 .4267 .9267 .9665 .92-3.67$ \\
\hline Jambi & $68.6968 .7568 .2 \quad 65.1165 .03-3.66$ \\
\hline Jawa Timur & $65.9766 .0265 .6464 .2664 .5 \quad-1.47$ \\
\hline Gorontalo & $65.2465 .7667 .1766 .7863 .2 \quad-2.04$ \\
\hline Bali & $66.6865 .4566 .4962 .2363 .18-3.5$ \\
\hline Nusa Tenggara Bara & $63.9964 .6763 .8164 .4 \quad 62.86-1.13$ \\
\hline Jawa Barat & $65.7664 .8164 .6264 .1661 .3-4.46$ \\
\hline Jawa Tengah & $64.8464 .4163 .6562 .1161 .05-3.79$ \\
\hline Banten & $62.2361 .2761 .8160 .6559 .97-2.26$ \\
\hline Sulawesi Tengah & $62.1761 .3362 .0160 .0558 .81-3.36$ \\
\hline DI Yogyakarta & $59.7562 .1860 .1859 .8957 .96-1.79$ \\
\hline Riau & $57.7858 .5857 \quad 54.5955 .97-1.81$ \\
\hline Kalimantan Timur & $61.8661 .8 \quad 59.5257 .4755 .41-6.45$ \\
\hline Kepulauan Riau & $57.9355 .9954 .4555 .1554 .13-3.8$ \\
\hline DKI Jakarta & $59.2158 .7856 .3856 .0953 .15-6.06$ \\
\hline Sulawesi Tenggara & 52.2254 .0453 .5449 .2852 .660 .44 \\
\hline Sulawesi Barat & $53.1 \quad 50.1950 .3 \quad 49.7551 .82-1.28$ \\
\hline Maluku Utara & $53.2251 .9552 .6749 .6 \quad 51.7 \quad-1.52$ \\
\hline Sumatera Barat & $53.0252 .4953 .3 \quad 50.6351 .28-1.74$ \\
\hline Sulawesi Selatan & $52.8952 .8653 .3850 .0650 .06-2.83$ \\
\hline Aceh & $53.0252 .7452 .3846 .5349 .45-3.57$ \\
\hline Sumatera Utara & $48.1848 .7148 .2245 .7845 .81-2.37$ \\
\hline Nusa Tenggara Tim & 40.5543 .5744 .2440 .3343 .73 .15 \\
\hline Papua Barat & $40.5 \quad 40.4741 .1138 .7341 .561 .06$ \\
\hline Maluku & $\begin{array}{lll}37.2 & 38.1139 .7 & 39.5436 .87-0.33\end{array}$ \\
\hline Papua & $25.3223 .5425 .8322 .1722 .76-2.56$ \\
\hline Total & $59.4459 .1959 .0257 .3957 .03-2.41$ \\
\hline
\end{tabular}


Table 2. Percentage of contraceptive use based on region, urban-rural, health insurance ownership, and the types of contraceptive methods

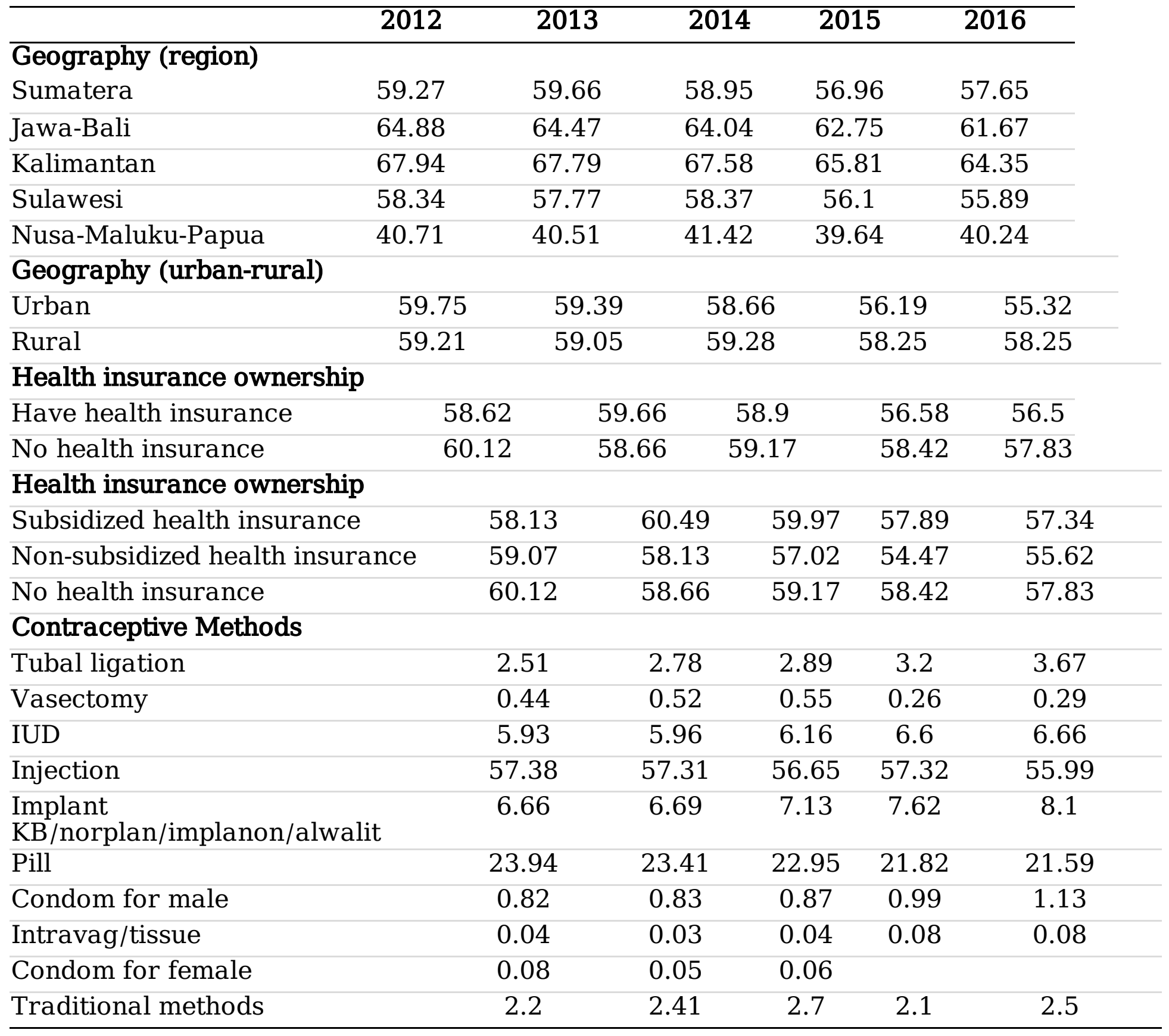

IUD: intrauterine device

Table 3. Bivariable analysis of health insurance ownership and utilization of 
Family Planning

\begin{tabular}{|c|c|c|c|c|c|}
\hline Province & 2012 & 2013 & 2014 & 2015 & 2016 \\
\hline Aceh & 0.256 & 0.970 & 0.267 & 0.888 & 0.627 \\
\hline Sumatera Utara & 0.062 & $<0.001 *$ & $0.006 *$ & 0.808 & $<0.001 *$ \\
\hline Sumatera Barat & 0.489 & 0.144 & 0.849 & $0.002^{* *}$ & 0.583 \\
\hline Riau & 0.853 & 0.457 & 0.144 & 0.521 & 0.074 \\
\hline Jambi & 0.975 & 0.578 & 0.246 & $<0.001^{* *}$ & 0.057 \\
\hline Sumatera Selatan & $0.001 * *$ & 0.141 & 0.207 & 0.055 & $0.046 *$ \\
\hline Bengkulu & 0.086 & 0.008* & 0.585 & 0.309 & $<0.001^{* *}$ \\
\hline Lampung & $<0.001^{* *}$ & k 0.473 & 0.216 & $0.031 * *$ & 0.468 \\
\hline Belitung & 0.751 & 0.159 & 0.056 & 0.077 & 0.195 \\
\hline Cepula & 0.052 & $0.002 *$ & 0.196 & 0.931 & 0.256 \\
\hline KI Jak & $0.006^{* *}$ & 0.950 & 0.309 & 0.866 & 0.462 \\
\hline Jawa & $0.038 *$ & 0.051 & 0.512 & 0.209 & 0.746 \\
\hline Jawa T & 0.615 & $0.003^{*}$ & $0.011 *$ & 0.967 & 0.860 \\
\hline DI Yog & $0.024 *$ & 0.456 & 0.095 & 0.063 & 0.172 \\
\hline Jawa & 0.923 & $<0.001 *$ & $0.019 *$ & $0.007 *$ & 0.878 \\
\hline Bante & 0.640 & 0.549 & 0.635 & 0.735 & 0.394 \\
\hline Bali & $0.030 *$ & $0.001 *$ & 0.119 & $0.001 *$ & $0.045^{*}$ \\
\hline Nusa & 0.129 & 0.372 & $0.002 *$ & 0.266 & 0.153 \\
\hline Nusa & 0.0 & 0.065 & $0.008^{*}$ & $<0.001 *$ & $0.008^{*}$ \\
\hline Kalin & & 0.950 & & 0.543 & 0.180 \\
\hline ali & 0.053 & $0.007 *$ & 0.958 & $0.003^{* *}$ & 0.245 \\
\hline alir & 0.728 & 0.416 & 0.739 & 0.206 & $0.006^{*}$ \\
\hline Kalir & 0.755 & $0.027 *$ & $0.004^{*}$ & 0.508 & 0.844 \\
\hline Sul & $020 * *$ & & & 413 & .189 \\
\hline & & & & 503 & $0.043 *$ \\
\hline & & & 0.836 & 0.754 & 0.995 \\
\hline & & $004^{*}$ & 0.4 & $0.002^{*}$ & $0.013^{*}$ \\
\hline & & & & 0.917 & 0.421 \\
\hline & & & & 0.928 & 0.673 \\
\hline & & & & 0.507 & 0.938 \\
\hline & & & $0.022 *$ & $0.014 *$ & 0.053 \\
\hline Papua Barat & 0.069 & $0.002 *$ & 0.101 & $<0.001 *$ & $0.002 *$ \\
\hline & $<0.001 *$ & $<0.001 *$ & $<0.001 *$ & $<0.001 *$ & $<0.001 *$ \\
\hline Indonesia & $<0.001 *$ & $50001 *$ & 0.235 & $<0.001 * *$ & $<0.001$ \\
\hline
\end{tabular}

*Significant positive $(p<0.05)$, directly proportional

$* *$ Significant negative $(p<0.05)$, inversely proportional

Table 4. Percentage of LACs use in married woman between 15 and 49 years of age 


\begin{tabular}{|c|c|c|}
\hline Province & \multicolumn{2}{|c|}{$201220132014201520162012-2016$} \\
\hline Bali & 39.5936 .3837 .6239 .8439 .89 & $\overline{0.3}$ \\
\hline Nusa Tenggara Timı & $28.5629 .4732 .65 \quad 34.436 .08$ & 7.52 \\
\hline DI Yogyakarta & 33.8133 .1235 .9637 .7435 .91 & 2.1 \\
\hline Gorontalo & 30.7929 .3830 .6832 .4932 .01 & 1.22 \\
\hline Sumatera Barat & 21.3924 .3924 .1425 .6328 .22 & 6.83 \\
\hline Sulawesi Utara & 23.7323 .5226 .4826 .4327 .03 & 3.3 \\
\hline Jawa Tengah & 21.2422 .5422 .9424 .0624 .87 & 3.63 \\
\hline Sumatera Utara & 19.6119 .7120 .5822 .6824 .72 & 5.11 \\
\hline DKI Jakarta & 19.0921 .7121 .9424 .8224 .32 & 5.23 \\
\hline Nusa Tenggara Bar & 20.1119 .1520 .1519 .9522 .68 & 2.57 \\
\hline Jawa Timur & 18.1318 .4219 .3319 .4219 .79 & 1.66 \\
\hline Bengkulu & $\begin{array}{lll}17.31 & 17.5517 .9219 .57 & 19.2\end{array}$ & 1.89 \\
\hline Maluku Utara & $\begin{array}{lll}12.54 & 1616.2113 .62 & 18.9\end{array}$ & 6.36 \\
\hline Sumatera Selatan & 11.5711 .4413 .4614 .7917 .51 & 5.94 \\
\hline Papua & $9.58 \quad 9.63 \quad 9.6611 .7317 .16$ & 7.58 \\
\hline Jawa Barat & 15.3214 .6414 .8117 .2316 .86 & 1.54 \\
\hline Kepulauan Riau & 11.3514 .4512 .3313 .0815 .35 & 4 \\
\hline Sulawesi Tenggara & 14.7114 .9615 .9612 .7414 .54 & -0.17 \\
\hline Sulawesi Tengah & 10.6713 .5114 .9113 .4214 .53 & 3.86 \\
\hline Banten & 11.0112 .1611 .7312 .1314 .36 & 3.35 \\
\hline Sulawesi Selatan & 10.359 .5111 .2112 .2414 .29 & 3.94 \\
\hline Maluku & 1213.4413 .4816 .0214 .05 & 2.05 \\
\hline Lampung & $10.5712 .2611 .75 \quad 13.513 .96$ & 3.39 \\
\hline Kalimantan Timur & $11.32 \quad 11.512 .5813 .3213 .75$ & 2.43 \\
\hline Riau & 9.1410 .3711 .8711 .3913 .73 & 4.59 \\
\hline Papua Barat & $6.88 \quad 8.9410 .0811 .2712 .66$ & 5.78 \\
\hline Jambi & 10.9811 .0610 .1611 .7512 .58 & 1.6 \\
\hline Sulawesi Barat & $10.96 \quad 9.4311 .7313 .1811 .96$ & 1 \\
\hline Aceh & $\begin{array}{lllll}5.82 & 5.9 & 6.75 & 8.43 & 9.65\end{array}$ & 3.83 \\
\hline Bangka Belitung & $\begin{array}{llll}7.44 & 8.06 & 8.3710 .54 & 9.49\end{array}$ & 2.05 \\
\hline Kalimantan Tengah & $\begin{array}{lllll}6.38 & 6.13 & 6.51 & 7.02 & 8.98\end{array}$ & 2.6 \\
\hline Kalimantan Barat & $\begin{array}{lllll}6.39 & 6.94 & 8.38 & 7.01 & 8.78\end{array}$ & 2.39 \\
\hline Kalimantan Selatan & $\begin{array}{lllll}7.04 & 6.7 & 6.7 & 7.23 & 7.33\end{array}$ & 0.29 \\
\hline Total & 15.5415 .9516 .7217 .6718 .72 & 3.18 \\
\hline
\end{tabular}

Table 5. Percentage of Long Acting Contraceptives use based on region, urban-rural, health insurance ownership 


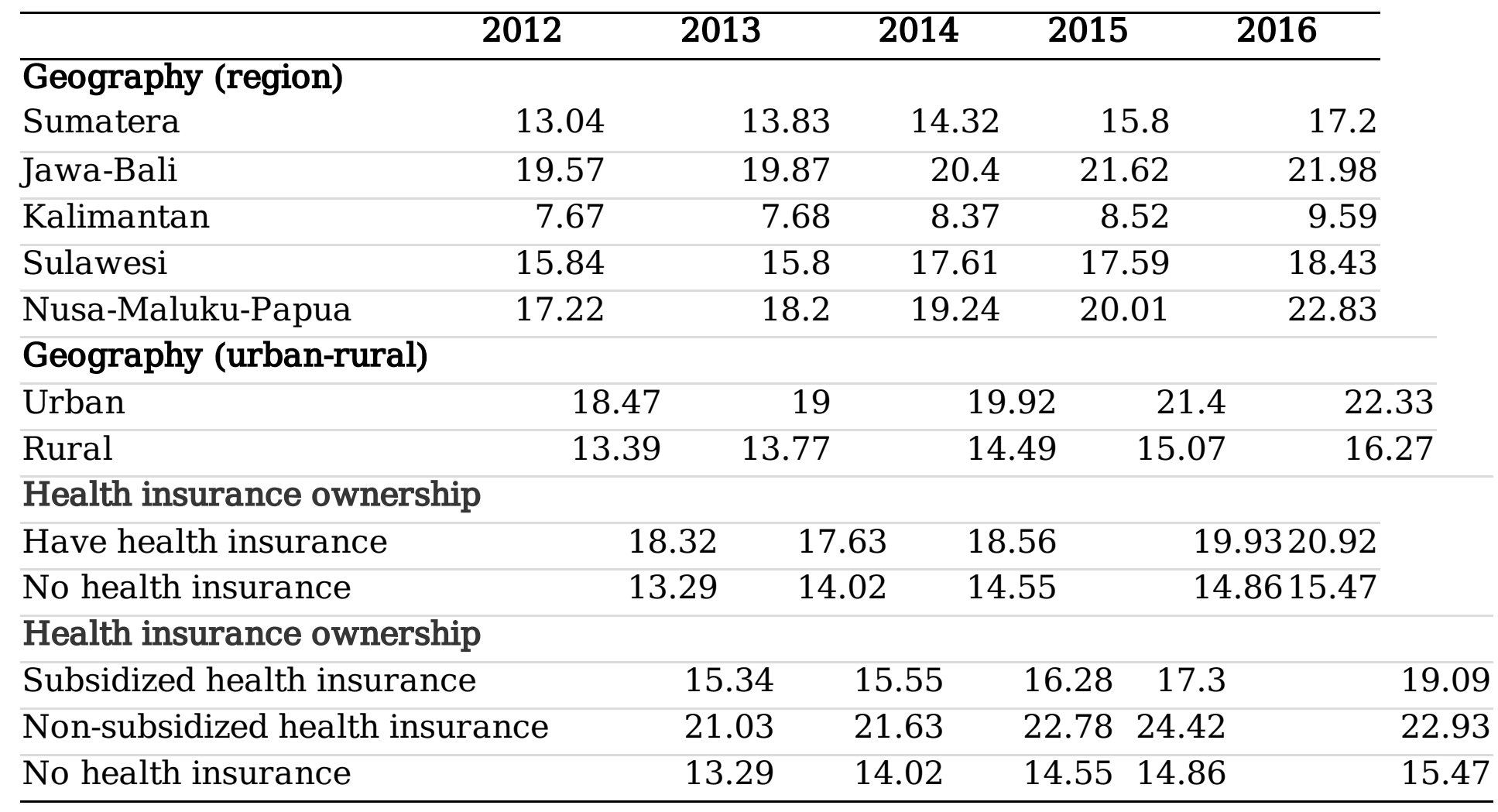

Table 6. Bivariable analysis of health insurance ownership and utilization of Long Acting Contraceptives 


\begin{tabular}{|c|c|c|c|c|c|}
\hline Province & 2012 & 2013 & 2014 & 2015 & 2016 \\
\hline$\overline{\text { Aceh }}$ & $0.001 *$ & 0.089 & 0.487 & 0.561 & 0.939 \\
\hline Sumatera Utara & $<0.001 *$ & $<0.001^{*}$ & $<0.001 *$ & ${ }^{k}<0.001 *$ & $<0.001 *$ \\
\hline Sumatera Barat & $<0.001 *$ & $<0.001^{*}$ & $<0.001 *$ & ${ }^{k}<0.001 *$ & $<0.001 *$ \\
\hline Riau & $<0.001 *$ & $<0.001 *$ & 0.088 & $<0.001 *$ & $<0.001 *$ \\
\hline Jambi & $<0.001 *$ & $<0.001^{*}$ & $0.007 *$ & $<0.001 *$ & $<0.001 *$ \\
\hline Sumatera Selatan & 0.107 & 0.710 & 0.301 & 0.151 & 0.232 \\
\hline Bengkulu & 0.350 & 0.236 & $<0.001^{*}$ & k.002* & 0.091 \\
\hline Lampung & 0.093 & 0.954 & 0.266 & $<0.001 *$ & $0.027 *$ \\
\hline Bangka Belitung & $0.033^{*}$ & 0.414 & 0.558 & 0.639 & $0.003 *$ \\
\hline Kepulauan Riau & 0.974 & 0.752 & 0.591 & $0.031 *$ & $0.005^{*}$ \\
\hline DKI Jakarta & $<0.001 *$ & $<0.001 *$ & 0.067 & $0.007 *$ & $0.002 *$ \\
\hline Jawa Barat & $<0.001 *$ & $<0.001^{*}$ & $<0.001 *$ & ${ }^{k}<0.001 *$ & $<0.001 *$ \\
\hline Jawa Tengah & $<0.001 *$ & 0.477 & 0.009* & $<0.001 *$ & $<0.001 *$ \\
\hline DI Yogyakarta & 0.210 & 0.851 & 0.152 & 0.275 & 0.056 \\
\hline Jawa Timur & $<0.001 *$ & $<0.001 *$ & $<0.001 *$ & $k<0.001 *$ & $<0.001 *$ \\
\hline Banten & $<0.001 *$ & $<0.001^{*}$ & $0.006 *$ & $<0.001 *$ & $<0.001 *$ \\
\hline Bali & $0.003^{*}$ & $0.002 *$ & $<0.001^{*}$ & k $0.002 *$ & $0.006^{*}$ \\
\hline Nusa Tenggara Barat & $<0.001 *$ & $0.019 *$ & $0.030 *$ & $0.027 *$ & $0.007 *$ \\
\hline Nusa Tenggara Timur & 0.430 & 0.229 & $0.036 *$ & $<0.001 *$ & $<0.001 *$ \\
\hline Kalimantan Barat & $<0.001 *$ & 0.926 & $<0.001^{*}$ & $k<0.001 *$ & $<0.001 *$ \\
\hline Kalimantan Tengah & $0.046^{*}$ & $0.001 *$ & $0.002 *$ & $<0.001 *$ & $<0.001 *$ \\
\hline Kalimantan Selatan & $<0.001 *$ & $<0.001 *$ & $0.001 *$ & $<0.001 *$ & 0.783 \\
\hline Kalimantan Timur & $<0.001 *$ & $<0.001^{*}$ & $<0.001 *$ & $k<0.001 *$ & $<0.001 *$ \\
\hline Sulawesi Utara & 0.540 & $0.004 *$ & $0.001 *$ & $0.012 *$ & $0.005 *$ \\
\hline Sulawesi Tengah & 0.058 & 0.808 & 0.988 & 0.242 & $<0.001 *$ \\
\hline Sulawesi Selatan & $<0.001 *$ & $0.005 *$ & $0.002 *$ & 0.060 & $0.002 *$ \\
\hline Sulawesi Tenggara & $<0.001 *$ & 0.058 & 0.862 & 0.446 & 0.175 \\
\hline Gorontalo & 0.365 & 0.119 & 0.674 & 0.422 & 0.476 \\
\hline Sulawesi Barat & 0.401 & 0.252 & $0.039 * *$ & 0.481 & 0.164 \\
\hline Maluku & 0.168 & 0.056 & $0.024 *$ & 0.900 & 0.061 \\
\hline Maluku Utara & 0.189 & $0.014 *$ & 0.125 & $<0.001 *$ & $0.018 *$ \\
\hline Papua Barat & 0.790 & 0.868 & 0.841 & $0.015 *$ & 0.879 \\
\hline Papua & $0.021 *$ & $<0.001 *$ & $<0.001 *$ & k 0.010* & $<0.001 *$ \\
\hline Indonesia & \multicolumn{5}{|c|}{$<0.001 *<0.001 *<0.001 *<0.001 *<0.001 *$} \\
\hline
\end{tabular}

*Significant positive $(p<0.05)$, directly proportional $* *$ Significant negative $(p<0.05)$, inversely proportional

Table 7. Bivariable Analysis: Determinants of contraceptive use in 2012-2016 


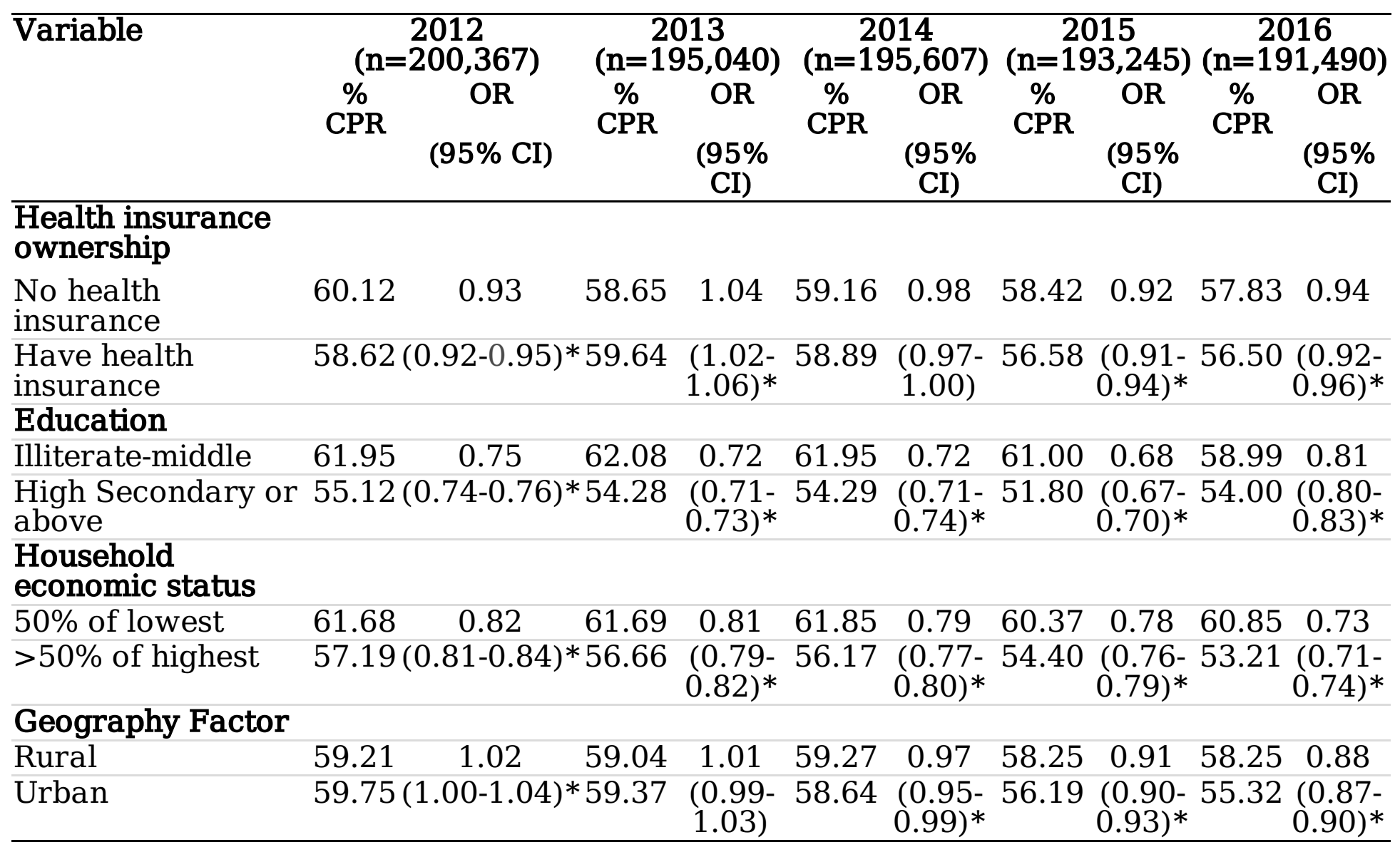

*Significant $p<0.05$; CI: Confidence Interval; CPR: Contraception Prevalence Rate; OR: Odds Ratio

Table 8. Bivariable Analysis: Determinants of Long Acting Contraceptives use in 2012-2016 


\begin{tabular}{|c|c|c|c|c|c|c|c|c|c|c|}
\hline \multirow[t]{3}{*}{ Variable } & \multicolumn{2}{|c|}{$\begin{array}{c}2012 \\
(n=119,096)\end{array}$} & \multicolumn{2}{|c|}{$\begin{array}{c}2013 \\
(n=115,450)\end{array}$} & \multicolumn{2}{|c|}{$\begin{array}{c}2014 \\
(\mathrm{n}=115,454)\end{array}$} & \multicolumn{2}{|c|}{$\begin{array}{c}2015 \\
(n=110,894)\end{array}$} & \multicolumn{2}{|c|}{$\begin{array}{c}2016 \\
(n=109,207)\end{array}$} \\
\hline & $\%$ & & $\%$ & OR & $\%$ & OR & $\%$ & & $\%$ & OR \\
\hline & \multicolumn{2}{|c|}{ LACs $(95 \%$ CI) } & & $\begin{array}{l}(95 \% \\
\mathrm{CI})\end{array}$ & & $\begin{array}{l}(95 \% \\
\mathrm{CI})\end{array}$ & & $\begin{array}{l}(95 \% \\
\mathrm{CI})\end{array}$ & & $\begin{array}{l}(95 \% \\
\mathrm{CI})\end{array}$ \\
\hline \multicolumn{11}{|l|}{$\begin{array}{l}\text { Health insurance } \\
\text { ownership }\end{array}$} \\
\hline No health insurance & 13.29 & 1.46 & 14.02 & 1.31 & 14.55 & 1.33 & 14.86 & 1.42 & 15.47 & 1.44 \\
\hline $\begin{array}{l}\text { Have health } \\
\text { insurance }\end{array}$ & 18.32 & $\begin{array}{l}(1.41- \\
1.51)^{*}\end{array}$ & 17.63 & $\begin{array}{l}(1.27- \\
1.35)^{*}\end{array}$ & 18.56 & $\begin{array}{l}(1.29- \\
1.38)^{*}\end{array}$ & 19.93 & $\begin{array}{l}(1.38- \\
1.47)^{*}\end{array}$ & 20.92 & $\begin{array}{l}(1.40- \\
1.49)^{*}\end{array}$ \\
\hline \multicolumn{11}{|l|}{ Education } \\
\hline Illiterate-middle & 13.24 & 1.63 & 13.45 & 1.68 & 14.40 & 1.57 & 14.96 & 1.65 & 15.89 & 1.62 \\
\hline $\begin{array}{l}\text { High Secondary or } \\
\text { above }\end{array}$ & 20.00 & $\begin{array}{l}(1.58- \\
1.69)^{*}\end{array}$ & 20.77 & $\begin{array}{l}(1.63- \\
1.74)^{*}\end{array}$ & 20.98 & $\begin{array}{l}(1.52- \\
1.62)^{*}\end{array}$ & 22.60 & $\begin{array}{l}(1.60- \\
1.71)^{*}\end{array}$ & 23.50 & $\begin{array}{l}(1.57- \\
1.67)^{*}\end{array}$ \\
\hline \multicolumn{11}{|l|}{$\begin{array}{l}\text { Household } \\
\text { economic status }\end{array}$} \\
\hline $50 \%$ of lowest & 14.04 & 1.26 & 14.22 & 1.30 & 15.28 & 1.24 & 16.07 & 1.26 & 17.07 & 1.26 \\
\hline$>50 \%$ of highest & 17.15 & $\begin{array}{l}(1.22- \\
1.30)^{*}\end{array}$ & 17.84 & $\begin{array}{l}(1.26- \\
1.35)^{*}\end{array}$ & 18.31 & $\begin{array}{l}(1.20- \\
1.28)^{*}\end{array}$ & 19.45 & $\begin{array}{l}(1.22- \\
1.30)^{*}\end{array}$ & 20.61 & $\begin{array}{l}(1.22- \\
1.30)^{*}\end{array}$ \\
\hline \multicolumn{11}{|l|}{ Geography Factor } \\
\hline Rural & 13.39 & 1.46 & 13.77 & 1.46 & 14.49 & 1.46 & 15.07 & 1.53 & 16.27 & 1.47 \\
\hline Urban & 18.47 & $\begin{array}{l}(1.41- \\
1.51)^{*}\end{array}$ & 19.00 & $\begin{array}{l}(1.42- \\
1.51)^{*}\end{array}$ & 19.92 & $\begin{array}{l}(1.42- \\
1.51)^{*}\end{array}$ & 21.40 & $\begin{array}{l}(1.48- \\
1.58)^{*}\end{array}$ & 22.33 & $\begin{array}{l}(1.43- \\
1.52)^{*}\end{array}$ \\
\hline
\end{tabular}

*Significant $p<0.05$; CI: Confidence Interval; LACs: Long Acting Contraceptives; OR: Odds Ratio

Table 9. Multivariable Analysis: Logistic Regression Determinants of contraceptive use in 2012-2016 


\begin{tabular}{|c|c|c|c|c|c|c|}
\hline \multirow[t]{2}{*}{ Variable } & \multicolumn{3}{|c|}{2012} & \multicolumn{3}{|c|}{2013} \\
\hline & Coefficient OR & $p$ & CI 95\% & \multicolumn{2}{|c|}{$\begin{array}{ll}\text { Coefficient OR } & p\end{array}$} & CI 95\% \\
\hline $\begin{array}{l}\text { Health insurance } \\
\text { ownership }\end{array}$ & -0.019 & 0.980 .031 & $\begin{array}{l}(0.96- \\
0.99)\end{array}$ & 0.047 & $1.04<0.001$ & $\begin{array}{l}(1.03- \\
1.06)\end{array}$ \\
\hline Education & -0.272 & $0.76<0.001$ & $\begin{array}{l}(0.74- \\
0.77)\end{array}$ & -0.313 & $0.73<0.001$ & $\begin{array}{l}(0.71- \\
0.74)\end{array}$ \\
\hline $\begin{array}{l}\text { Household economic } \\
\text { status }\end{array}$ & -0.147 & $0.86<0.001$ & $\begin{array}{l}(0.84- \\
0.87)\end{array}$ & -0.161 & $0.85<0.001$ & $\begin{array}{l}(0.83- \\
0.86)\end{array}$ \\
\hline Geography Factor & 0.127 & $1.13<0.001$ & $\begin{array}{l}(1.11- \\
1.15)\end{array}$ & 0.123 & $1.13<0.001$ & $\begin{array}{l}(1.10- \\
1.15)\end{array}$ \\
\hline \multirow[t]{3}{*}{ Constant } & \multicolumn{2}{|l|}{-0.201} & & \multicolumn{2}{|l|}{-0.191} & \\
\hline & \multicolumn{3}{|c|}{2014} & \multicolumn{3}{|c|}{2015} \\
\hline & \multicolumn{2}{|c|}{$\begin{array}{ll}\text { Coefficient OR } & p\end{array}$} & CI 95\% & \multicolumn{2}{|c|}{$\begin{array}{ll}\text { Coefficient OR } & p\end{array}$} & CI 95\% \\
\hline $\begin{array}{l}\text { Health insurance } \\
\text { ownership }\end{array}$ & \multirow[b]{2}{*}{-0.289} & $>0.05$ & \multirow[b]{2}{*}{$\begin{array}{l}(0.73- \\
0.76)\end{array}$} & -0.041 & $0.95<0.001$ & $\begin{array}{l}(0.94- \\
0.97)\end{array}$ \\
\hline Education & & $0.74<0.001$ & & -0.337 & $0.71<0.001$ & $\begin{array}{l}(0.70- \\
0.72)\end{array}$ \\
\hline $\begin{array}{l}\text { Household economic } \\
\text { status }\end{array}$ & -0.184 & $0.83<0.001$ & $\begin{array}{l}(0.81- \\
0.84)\end{array}$ & -0.169 & $0.84<0.001$ & $\begin{array}{l}(0.82- \\
0.86)\end{array}$ \\
\hline Geography Factor & 0.079 & $1.08<0.001$ & $\begin{array}{l}(1.06- \\
1.10)\end{array}$ & 0.034 & $1.03<0.001$ & $\begin{array}{l}(1.01- \\
1.05)\end{array}$ \\
\hline \multirow[t]{3}{*}{ Constant } & -0.143 & & & -0.012 & & \\
\hline & \multicolumn{3}{|c|}{2016} & & & \\
\hline & \multirow{2}{*}{\multicolumn{2}{|c|}{$\begin{array}{ccc}\text { Coefficient OR } & \boldsymbol{p} \\
-0.025 & 0.97 & 0.007\end{array}$}} & CI 95\% & & & \\
\hline \multirow{2}{*}{$\begin{array}{l}\text { Health insurance } \\
\text { ownership } \\
\text { Education }\end{array}$} & & & $\begin{array}{l}(0.95- \\
0.99)\end{array}$ & & & \\
\hline & -0.120 & $0.88<0.001$ & $\begin{array}{l}(0.86- \\
0.90)\end{array}$ & & & \\
\hline $\begin{array}{l}\text { Household economic } \\
\text { status }\end{array}$ & -0.274 & $0.75<0.001$ & $\begin{array}{l}(0.74- \\
0.77)\end{array}$ & & & \\
\hline Geography Factor & -0.030 & 0.960 .002 & $\begin{array}{l}(0.95- \\
0.98)\end{array}$ & & & \\
\hline Constant & -0.046 & & & & & \\
\hline
\end{tabular}

Significant $p<0.05$; CI: Confidence Interval; OR: Odds Ratio

Table 10. Multivariable Analysis: Logistic Regression Determinants of Long Acting Contraceptives Use in 2012-2016 


\begin{tabular}{|c|c|c|c|c|c|c|}
\hline \multirow[t]{2}{*}{ Variable } & \multicolumn{3}{|c|}{2012} & \multicolumn{3}{|c|}{2013} \\
\hline & \multicolumn{2}{|c|}{$\begin{array}{ll}\text { Coefficient OR } & p\end{array}$} & CI 95\% & \multicolumn{3}{|c|}{$\begin{array}{lll}\text { Coefficient OR } & \boldsymbol{p} & \text { CI 95\% }\end{array}$} \\
\hline $\begin{array}{l}\text { Health insurance } \\
\text { ownership }\end{array}$ & 0.301 & $1.35<0.001$ & \multirow{2}{*}{$\begin{array}{l}(1.30- \\
1.39) \\
(1.38- \\
1.47)\end{array}$} & 0.256 & $1.29<0.001$ & $\begin{array}{l}(1.25- \\
1.33)\end{array}$ \\
\hline Education & 0.357 & $1.42<0.001$ & & 0.412 & $1.51<0.001$ & $\begin{array}{l}(1.45- \\
1.56)\end{array}$ \\
\hline $\begin{array}{l}\text { Household economic } \\
\text { status }\end{array}$ & 0.060 & $1.06<0.001$ & $\begin{array}{l}(1.02- \\
1.09)\end{array}$ & 0.121 & $1.12<0.001$ & $\begin{array}{l}(1.09- \\
1.16)\end{array}$ \\
\hline Geography Factor & 0.250 & $1.28<0.001$ & $\begin{array}{l}(1.24- \\
1.32)\end{array}$ & 0.256 & $1.29<0.001$ & $\begin{array}{l}(1.25- \\
1.33)\end{array}$ \\
\hline \multirow[t]{3}{*}{ Constant } & \multicolumn{2}{|l|}{1.147} & & \multicolumn{2}{|l|}{1.091} & \\
\hline & \multicolumn{3}{|c|}{2014} & \multicolumn{3}{|c|}{2015} \\
\hline & \multicolumn{2}{|c|}{$\begin{array}{ll}\text { Coefficient OR } & p\end{array}$} & CI 95\% & \multicolumn{2}{|c|}{ Coefficient OR $p$} & CI 95\% \\
\hline $\begin{array}{l}\text { Health insurance } \\
\text { ownership }\end{array}$ & 0.270 & $1.31<0.001$ & $\begin{array}{l}(1.26- \\
1.35)\end{array}$ & 0.308 & $1.36<0.001$ & $\begin{array}{l}(1.31- \\
1.40)\end{array}$ \\
\hline Education & 0.349 & $1.41<0.001$ & $\begin{array}{l}(1.37- \\
1.46)\end{array}$ & 0.378 & $1.45<0.001$ & $\begin{array}{l}(1.41- \\
1.50)\end{array}$ \\
\hline $\begin{array}{l}\text { Household economic } \\
\text { status }\end{array}$ & 0.087 & $1.09<0.001$ & $\begin{array}{l}(1.05- \\
1.12)\end{array}$ & 0.076 & $1.07<0.001$ & $\begin{array}{l}(1.04- \\
1.11)\end{array}$ \\
\hline Geography Factor & 0.278 & $1.32<0.001$ & $\begin{array}{l}(1.27- \\
1.36)\end{array}$ & 0.305 & $1.35<0.001$ & $\begin{array}{l}(1.31- \\
1.40)\end{array}$ \\
\hline \multirow[t]{3}{*}{ Constant } & 1.074 & & & 0.971 & & \\
\hline & & 2016 & & & & \\
\hline & \multicolumn{2}{|c|}{ Coefficient OR $\quad \mu$} & CI 95\% & & & \\
\hline $\begin{array}{l}\text { Health insurance } \\
\text { ownership }\end{array}$ & 0.317 & $1.37<0.001$ & $\begin{array}{l}(1.32- \\
1.41)\end{array}$ & & & \\
\hline Education & 0.371 & $1.44<0.001$ & $\begin{array}{l}(1.40- \\
1.49)\end{array}$ & & & \\
\hline $\begin{array}{l}\text { Household economic } \\
\text { status }\end{array}$ & 0.076 & $1.07<0.001$ & $\begin{array}{l}(1.04- \\
1.11)\end{array}$ & & & \\
\hline Geography Factor & 0.265 & $1.30<0.001$ & $\begin{array}{l}(1.26- \\
1.34)\end{array}$ & & & \\
\hline Constant & 0.938 & & & & & \\
\hline
\end{tabular}

Significant $p<0.05$; CI: Confidence Interval; OR: Odds Ratio

\section{Supplementary Files}

This is a list of supplementary files associated with this preprint. Click to download.

- supplement1.docx 